\title{
EXTREME HOMOGENEITY AMONG BRAZILIAN WHEAT GENOTYPES DETERMINED BY RAPD MARKERS'
}

\author{
LORETA BRANDÃO DE FREITAS ${ }^{2}$, LEANDRO JERUSALINSKY³, SANDRO LUIS BONATTO ${ }^{4}$ \\ and FRANCISCO MAURO SALZANO ${ }^{5}$
}

\begin{abstract}
Random amplified polymorphic DNA markers (RAPD) were used to estimate the variability of 14 genotypes of Brazilian wheat (Triticum aestivum L.), using a set of 50 random 10-mer primers. A total of 256 reproducibly scorable DNA amplification products were obtained from 48 of the primers, $83 \%$ of which were polymorphic. Genetic distances among genotypes were calculated and a dendrogram and a principal coordinates analysis showing the genetic relationships among them were obtained. Despite the low variability found (average genetic distance of 27\%), two groups of genotypes could be identified, which probably reflect how they were formed. Studies such as this one may be important in the planning and development of future improvement programs for this plant species.
\end{abstract}

Index terms: Triticum aestivum, genetic variation, polymorphism, breeding methods.

\section{EXTREMA HOMOGENEIDADE ENTRE GENÓTIPOS BRASILEIROS DE TRIGO DETERMINADA POR MARCADORES DE "RAPD"}

\begin{abstract}
RESUMO - Marcadores de RAPD (Random amplified polymorphic DNA) foram utilizados para estimar o grau de variabilidade genética entre 14 genótipos de trigo (Triticum aestivum $\mathrm{L}$.) cultivados no Brasil, usando um conjunto de 50 "primers" aleatórios de 10 pares de bases (pb). Um total de 256 fragmentos de amplificação foram obtidos de 48 dos "primers" analisados. Destes, $83 \%$ eram polimórficos. Foram estimadas as distâncias genéticas entre os genótipos e a análise de um dendrograma e das coordenadas principais mostraram as relações genéticas entre eles. A despeito do baixo índice de variabilidade genética observado entre os genótipos (distância genética média de 27\%), estes puderam ser reunidos em dois grupos, provavelmente relacionados à sua ancestralidade. Estudos como este podem ser importantes no planejamento e desenvolvimento de programas futuros para melhoramento desta espécie de planta.
\end{abstract}

Termos para indexação: Triticum aestivum, variação genética, polimorfismo, métodos de melhoramento.

\footnotetext{
${ }^{1}$ Accepted for publication on February 2, 2000.

${ }^{2}$ Biologist, Ph.D., Associate Professor, Dep. de Genética, Instituto de Biociências (IB), Universidade Federal do Rio Grande do Sul (UFRGS), Caixa Postal 15053, CEP 91501-970 Porto Alegre, RS. E-mail: loreta@if.ufrgs.br

${ }^{3}$ Biologist, Dep. de Genética, IB, UFRGS.

E-mail: lejerusa@vortex.ufrgs.br

${ }^{4}$ Biologist, Ph.D., Associate Professor, Faculdade de Biociências, Pontifícia Universidade Católica do Rio Grande do Sul, Av. Ipiranga 6690, CEP 90619-900 Porto Alegre, RS. E-mail: slbonatto@music.pcrs.br

${ }^{5}$ Biologist, Ph.D., Dep. de Genética, IB, UFRGS.

E-mail: salzano@if.ufrgs.br
}

\section{INTRODUCTION}

Random amplified polymorphic DNA (RAPD) has been widely used to determine the genetic variability within species and show relationships among populations. This technique has recently been employed to investigate a wide variety of plants, such as Stylosanthes (Kazan et al., 1993), Carica (Stiles et al., 1993), Lycopersicon (Williams \& St. Clair, 1993), Avena (Heun et al., 1994), Paspalum (Liu et al., 1994), Theobroma (N'Goram et al., 1994), Lens (Abo-Elwafa et al., 1995), Medicago (Brummer et al., 1995), Rubus 
(Graham \& McNicol, 1995), Allium (Maab \& Klaas, 1995), Zea (Lanza et al., 1997), and Manihot (Colombo et al., 1998). Its technical simplicity has facilitated its use in the analysis of genetic variability, with results being successfully correlated with established relationships based on pedigree records (Kresovich et al., 1992; Yang \& Quiros, 1993; Stiles et al., 1993; Liu et al., 1994). Triticum aestivum is an autogamous and hexaploid species that is largely used in human nutrition and had been intensely cultivated and improved.

In this paper RAPD markers were used to evaluate the variability and interrelationships of 14 Brazilian wheat genotypes.

\section{MATERIAL AND METHODS}

\section{Wheat genotypes}

Fourteen Brazilian genotypes were supplied by the Embrapa-Centro Nacional de Pesquisa do Trigo, Passo Fundo, RS, Brazil: PF 8914, PF 9027, PF 89119, PF 89339, PF 889199, PF 889300, BR 23, BR 32, BR 35, BR 43, IAC 13, TOROPI, PF 844002, and PF 844007 (Table 1). These genotypes had been analyzed for other parameters, and were being used in experimental assay net or had been recommended for cultivation. Therefore, the results obtained could be compared with other types of data, providing a global assessment of the problems considered.

\section{DNA template}

High-molecular-weight genomic DNA was extracted from leaves of 21 day-old plants developed in a growth chamber. The DNA extraction procedure was described by Roy et al. (1992). About $0.5 \mathrm{~g}$ of tissue was ground in liquid nitrogen and incubated with a lyses buffer $(100 \mathrm{mM}$ TRIS, $1.4 \mathrm{mM} \mathrm{NaCl}, 20 \mathrm{mM}$ EDTA, 2\% CTAB, $0.2 \%$ beta-mercaptoethanol) at $65^{\circ} \mathrm{C}$ for 30 minutes. The resulting slurry was then treated with chloroform:isoamyl alcohol (24:1) and centrifuged at 12,000 rpm for 15 minutes. The aqueous phase was separated, and DNA was then precipitated from it using an equal volume of isopropanol and $1 / 10$ volume $3 \mathrm{M} \mathrm{C}_{2} \mathrm{H}_{3} \mathrm{O}_{2} \mathrm{Na}$, pelleted, and suspended in sterile water.

\section{RAPD materials}

Fifty arbitrarily designed primers of ten deoxyribonucleotides were obtained from the Biotechnology Laboratory of British Columbia, Canada (primers nos. 201-250). The Taq DNA polymerase, plus the 10x concentrated PCR buffer, was supplied by the Biotechnology Center, Universidade Federal do Rio Grande do Sul, while the dNTPs sets were obtained from Amersham. Amplifications were carried out in a PerkinElmer Cetus DNA Thermal Cycler.

\section{Amplification conditions}

The amplification conditions were rigorously tested in optimization experiments. A standard procedure was

TABLE 1. Wheat performance in relation to diseases and genealogical information on the genotypes investigated (Embrapa-CNPT).

\begin{tabular}{|c|c|c|c|c|c|c|}
\hline \multirow[t]{3}{*}{ Genotype } & \multicolumn{5}{|c|}{ Performance in relation to disease ${ }^{1}$} & \multirow[t]{3}{*}{ Genealogical information on common ancestry } \\
\hline & \multirow[t]{2}{*}{ Oidio } & \multirow[t]{2}{*}{ Septoria_ } & \multicolumn{2}{|c|}{ Rust } & \multirow[t]{2}{*}{ Giberella } & \\
\hline & & & $\mathrm{S}$ & $\mathrm{L}$ & & \\
\hline $1-\mathrm{PF} 8914$ & ++ & + & * & ++ & * & F22449/F72848 \\
\hline 2 - PF9027 & * & * & * & * & * & BR14/4/PF839197/3/LONDRINA/COKER76-35//F20565/F16955 \\
\hline 3 - PF89119 & $*$ & * & $*$ & $*$ & $*$ & CEP14*2/PF79782 \\
\hline 4 - PF89339 & $*$ & * & * & * & * & COKER762/PF8390 \\
\hline 5 - PF889199 & ++ & - & * & -- & * & PF839197/5/F16946/3/NBAY*2//LD*2/ALD SIB/4/F16955 \\
\hline $6-\mathrm{PF} 889300$ & $*$ & * & * & $*$ & $*$ & BR35//COKER762/IAC5 \\
\hline $7-\mathrm{BR} 23$ & -- & - & ++ & - & -- & CORRE CAMINOS/ALD SIB/3/IAS54-20/COP//CNT8 \\
\hline $8-\mathrm{BR} 32$ & -- & + & ++ & + & -- & IAS60/INDUS//IAS62/3/ALD SIB/4/IAS59 \\
\hline $9-\mathrm{BR} 35$ & \pm & + & \pm & - & -- & IAC5*2/3/CNT7*3/LD//IAC5/HADEN \\
\hline $10-\mathrm{BR} 43$ & -- & -- & ++ & -- & - & PF833007/JACUÍ \\
\hline $11-\mathrm{IAC} 13$ & -- & * & -- & * & -- & CIANO67/IAS51 \\
\hline 12 -TOROPI & -- & * & \pm & $*$ & \pm & PETIBLANCO8//FRONTANA/QUADERNA A \\
\hline $13-\mathrm{PF} 844004$ & ++ & - & $*$ & ++ & \pm & Triticum durum NE22909/Aegylops squarrosa NE20229-C \\
\hline $14-\mathrm{PF} 844007$ & ++ & + & $*$ & ++ & * & Triticum durum NE22912/Aegylops squarrosa NE29341 \\
\hline
\end{tabular}

${ }^{1}$ S: stem; L: leaf ; ++: resistant; +: partially resistant; \pm : intermediate; -: partially susceptible; -- susceptible; *: not available. 
arrived at, based on Williams et al. (1990) protocol. The PCR volume was $25 \mu \mathrm{L}$ and contained $0.2 \mu \mathrm{M}$ primer, $0.2 \mathrm{mM}$ dNTPs, $2.5 \mathrm{U}$ of Taq DNA polymerase, 1x PCR buffer (10 mM TRIS-HCI pH 8.3, $1.5 \mathrm{mM} \mathrm{MgCl}_{2}, 50 \mathrm{mM}$ $\mathrm{KCl}$ ), and $10 \mathrm{ng}$ template DNA. During the manipulation the tubes were kept on ice. The reaction mixtures were overlaid with mineral oil and subjected to PCR. Standard amplifications were performed at 45 cycles of $30 \mathrm{sec}$ at $94^{\circ} \mathrm{C}, 30 \mathrm{sec}$ at $35^{\circ} \mathrm{C}$, and $30 \mathrm{sec}$ at $72^{\circ} \mathrm{C}$. After the last cycle, the samples were kept at $72^{\circ} \mathrm{C}$ for additional $5 \mathrm{~min}$ and then cooled to $4^{\circ} \mathrm{C}$. Samples of $10 \mu \mathrm{L}$ were analyzed by electrophoresis on a $1.5 \%$ agarose gel, and the amplified products were detected with ethidium bromide staining.

\section{Data analysis}

Estimates of genetic distances were calculated by the King et al. (1993) method, and the dendrogram obtained by neighbor-joining (Saitou \& Nei, 1987), using the Treecon for Windows package (Peer \& Wachter, 1994).

\section{RESULTS AND DISCUSSION}

As previously mentioned, fifty arbitrary decamer primers were screened for their suitability to detect variation in PCR reactions with Brazilian wheat DNA templates. Of these, 48 amplified DNA, and 83\% amplified polymorphic products. A total of 256 bands from 320 to $570 \mathrm{bp}$ in size were scored as being present or absent per primer reaction. Each primer amplified two to ten bands, the majority producing four fragments. All of these markers showed the same pattern in three separate RAPD runs, for which the same amplification conditions have been used. Representative examples of runs are shown in Fig. 1.

The average genetic distance among these genotypes, based on RAPD data, was $27 \%$, the lowest value being $14 \%$ between genotypes 11 and 12 (Table 2), and the highest, $40 \%$ between genotypes 3 and 11 . This homogeneity of $73 \%$ is probably due to the fact that all the wheat genotypes used in Brazil have a common origin. Similar (though not as extreme) RAPD results were also obtained with British (Devos \& Gale, 1992) or USA (He et al., 1992) varieties, but Sun et al. (1998) also found extreme homogeneity (79\% to $88 \%$, using 32 arbitrary primers) among respectively Chinese winter and spring common wheat. He et al. (1992) combined RAPD analysis with the DGGE (denaturing gradient gel electrophoresis) technique, and even with this potentially more discriminating combination obtained an overall similarity index of $62 \%$. Quantitative estimates of genetic homogeneity based on RAPD markers were obtained by Lanza et al. (1997) in maize (37\%), Graham \& McNicol (1995) in Rubus (61\%), Williams \& St. Clair (1993) in tomato (63\%), and Colombo et al. (1998) in Manihot $(65 \%)$. The homogeneity observed in wheat, especially in Brazil, should be a question of concern to breeders, since it can lead to generalized liability to diseases and other noxious agents.

The dendrogram obtained from the genetic distances shows two distinct groups (group 1, genotypes 1,2, 3, 5, 7 and 8; group 2, genotypes 4, 6 , $9,10,11,12,13$ and 14) that are internally rather homogeneous (Fig. 2). The principal coordinates data

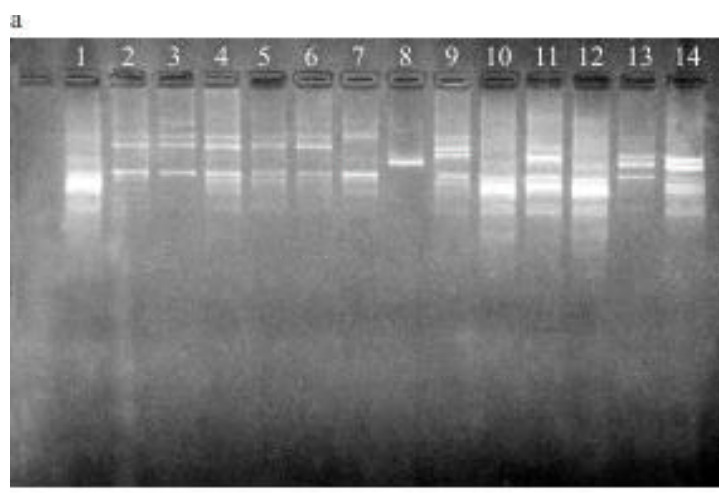

b

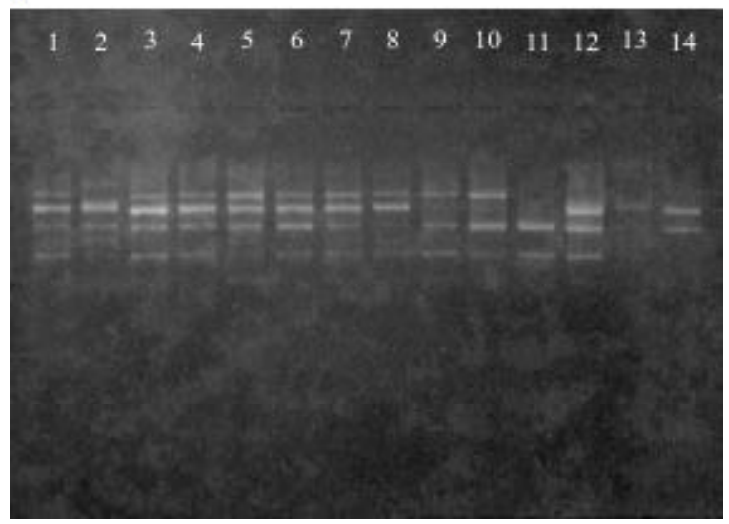

FIG . 1. Random amplified polymorphic DNA (RAPD) patterns found in 14 Brazilian wheat genotypes using primer 212 (a) and 242 (b). 
TABLE 2. Genetic distances matrix obtained from the randon amplified polymorphic DNA (RAPD) results using 48 primers in 14 Brazilian wheat genotypes.

\begin{tabular}{|c|c|c|c|c|c|c|c|c|c|c|c|c|c|}
\hline Genotype & 1 & 2 & 3 & 4 & 5 & 6 & 7 & 8 & 9 & 10 & 11 & 12 & 13 \\
\hline 2 & 0.254 & & & & & & & & & & & & \\
\hline 3 & 0.279 & 0.233 & & & & & & & & & & & \\
\hline 4 & 0.258 & 0.282 & 0.290 & & & & & & & & & & \\
\hline 5 & 0.253 & 0.226 & 0.277 & 0.212 & & & & & & & & & \\
\hline 6 & 0.286 & 0.260 & 0.300 & 0.167 & 0.250 & & & & & & & & \\
\hline 7 & 0.266 & 0.240 & 0.289 & 0.261 & 0.239 & 0.255 & & & & & & & \\
\hline 8 & 0.286 & 0.259 & 0.310 & 0.279 & 0.231 & 0.290 & 0.210 & & & & & & \\
\hline 9 & 0.296 & 0.294 & 0.302 & 0.170 & 0.261 & 0.209 & 0.257 & 0.267 & & & & & \\
\hline 10 & 0.287 & 0.286 & 0.302 & 0.204 & 0.251 & 0.171 & 0.256 & 0.291 & 0.174 & & & & \\
\hline 11 & 0.327 & 0.324 & 0.395 & 0.214 & 0.316 & 0.216 & 0.280 & 0.346 & 0.227 & 0.191 & & & \\
\hline 12 & 0.338 & 0.319 & 0.361 & 0.257 & 0.343 & 0.243 & 0.306 & 0.317 & 0.220 & 0.227 & 0.137 & & \\
\hline 13 & 0.300 & 0.273 & 0.364 & 0.333 & 0.330 & 0.287 & 0.284 & 0.304 & 0.313 & 0.313 & 0.296 & 0.256 & \\
\hline 14 & 0.298 & 0.327 & 0.360 & 0.250 & 0.319 & 0.252 & 0.274 & 0.293 & 0.263 & 0.254 & 0.237 & 0.288 & 0.266 \\
\hline
\end{tabular}

confirm this result (Fig. 3). Attempts to relate these groups to characteristics of agronomic value, specially reaction to diseases, were unsuccessful. For instance, genotypes 11 and 12, which associated closely in the dendrogram, show a completely different behavior in relation to the stem rust disease, genotype 11 being susceptible and genotype 12 partially resistant to this fungus infection. Other high indices of similarity were found between genotypes who had one or more common ancestors (for instance, genotypes 6 and 4, or 7 and 8). The relationships observed, therefore, may reflect more the history of genotype formation than any other factor.

Since the onset of civilization, plant diseases have had catastrophic effects on crops and the well-being of human populations. Infectious plant diseases continue to cause human suffering and enormous economic losses. Increasing human population and decreasing amounts of land available for agriculture make all approaches to securing the world food supply critical. Protection of crops from disease can substantially improve agricultural production. Although pesticides have successfully controlled disease, their continued and increasing use will have harmful effects on our health and the environment. Use of high-yield crop varieties can also improve productivity, but carries a risk - such genetically uniform varieties cultivated over enormous areas are susceptible to devastating epidemics. Thoughtful application to the plants own defense mechanisms, combined with additional genetic variability, can lead to more effective protection against plant pathogens (Baker et al., 1997).

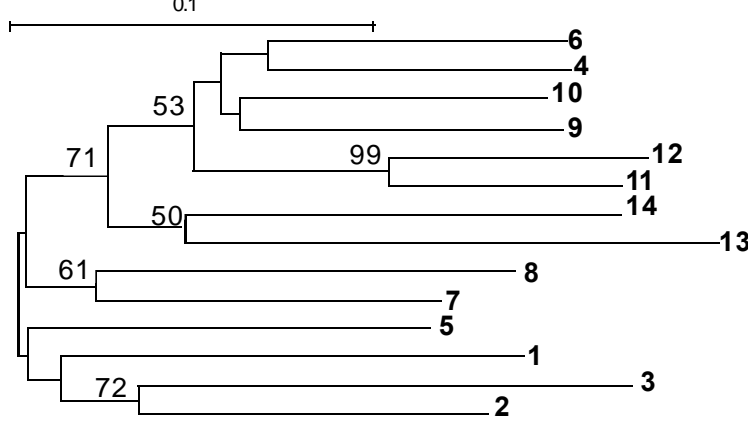

FIG. 2. Dendrogram obtained from the genetic distances calculated between the 14 Brazilian wheat genotypes. Numbers on the nodes are bootstrap values.

There is an increasing awareness that variability profoundly affects host-parasite interactions. Variability should therefore be considered in the design of programs to control diseases and should influence decisions about the establishment and management of natural reserves for endangered species. One of the problems in doing so is that variability occurs at several levels of biological organization: among populations, within populations and within individuals. The question is to decide which of these levels is the most relevant for the dynamics and evolution of disease. Because each level has a qualitatively different effect on the hostparasite relationships, it seems unlikely that there will be a simple and general answer to this question (Schmid-Hempel \& Koella, 1994). In the case of organisms of economic interest, the situation is 


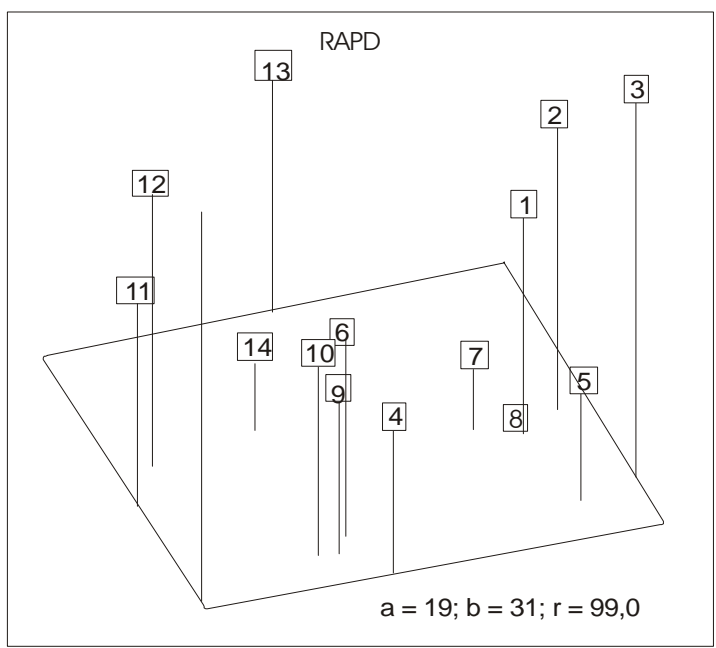

FIG. 3. Principal coordinates analysis applied to the genetic distances matrix obtained from 14 Brazilian wheat genotypes.

worsened, since the type of genetic improvement employed to obtain varieties and races may lead to a disequilibrium in the relationship between defense and attack developed in the course of the evolutionary history of organisms. Human intervention could lead to the extinction of defense genes whose secondary effects may affect yield.

Additional genetic variability should be sought for wheat genotypes, either through related species or by genetic engineering, with the objective of improving the potential of defense against diseases of this important cultivated plant. Sun et al. (1998) suggest crosses with the Tibetan wheat. This subspecies has a high level of genetic heterogeneity and is easily crossable with other wheat, yielding highly fertile $F_{1}$.

\section{CONCLUSION}

Seventy eight percent of the RAPD bands are shared by the analyzed genotypes.

\section{ACKNOWLEDGMENTS}

To Ariano Prestes, Maria Irene B. Moraes Fernandes, and Sandra P. Brammer, from Embrapa-
Centro Nacional de Pesquisa de Trigo, for the provision of material and information; to Suzana Cavalli-Molina of our Department, for laboratory space; to Programa de Apoio a Núcleos de Excelência (PRONEX), Financiadora de Estudos e Projetos (FINEP), Conselho Nacional de Desenvolvimento Científico e Tecnológico (CNPq), Fundação de Amparo à Pesquisa do Estado do Rio Grande do Sul (FAPERGS), and Pró-Reitoria de Pesquisa, Universidade Federal do Rio Grande do Sul (PROPESQUFRGS) for research grants.

\section{REFERENCES}

ABO-ELWAFA, A.; MURAI, K.; SHIMADA, T. Intra and inter-specific variations in Lens revealed by RAPD markers. Theoretical and Applied Genetics, Berlin, v.90, p.335-340, 1995.

BAKER, B.; ZAMBRYSKI, P.; STASKAWICZ, S.P.; DINESH-KUMAR, S.P. Signaling in plant-microbe interactions. Science, Washington, v.276, p.726-733, 1997.

BRUMMER, E.C.; BOUTON, J.H.; KOCHERT, G. Analysis of annual Medicago species using RAPD markers. Genome, Ottawa, v.38, p.362-367, 1995.

COLOMBO, C.; SECOND, G.; VALLE, T.L.; CHARRIER, A. Genetic diversity characterization of cassava cultivars (Manihot esculenta Crantz). I. RAPD markers. Genetics and Molecular Biology, Ribeirão Preto, v.21, p.105-113, 1998.

DEVOS, K.M.; GALE, M.D. The use of random amplified polymorphic DNA markers in wheat. Theoretical and Applied Genetics, Berlin, v.84, p.567-572, 1992.

GRAHAM, J.; McNICOL, R.J. An examination of the ability of RAPD markers to determine the relationships within and between Rubus species. Theoretical and Applied Genetics, Berlin, v.90, p.1128-1132, 1995.

HE, S.; OHM, H.; MACKENZIE, S. Detection of DNA sequence polymorphisms among wheat varieties. Theoretical and Applied Genetics, Berlin, v.84, p.573-578, 1992.

HEUN, M.; MURPHY, J.P.; PHILlIPS, T.D. A comparison of RAPD and isozyme analysis for determining the genetic relationships among Avena sterilis L. accessions. Theoretical and Applied Genetics, Berlin, v.87, p.689-696, 1994. 
KAZAN, K.; MANNERS, J.M.; CAMERON, D.F. Inheritance of random amplified polymorphic DNA markers in an interspecific cross in the genus Stylosanthes. Genome, Ottawa, v.36, p.145-156, 1993.

KING, G.; NIENHUIS, J.; HUSSEY, C. Genetic similarity among ecotypes of Arabidopsis thaliana estimated by analysis of restriction fragment length polymorphisms. Theoretical and Applied Genetics, Berlin, v.86, p.1028-1032, 1993.

KRESOVICH, S.; WILLIAMS, J.G.K.; McFERSON, J.R.; ROUTMAN, E.J.; SCAAL, B.A. Characterization of genetic identities and relationships of Brassica oleraceae $\mathrm{L}$. via a random amplified polymorphic DNA assay. Theoretical and Applied Genetics, Berlin, v.85, p.190-196, 1992.

LANZA, L.L.B.; SOUZA JUNIOR, C.L. de; OTTOBONI, L.M.M.; VIEIRA, M.L.C.; SOUZA, A.P. Genetic distance of inbred lines and prediction of maize singlecross performance using RAPD markers. Theoretical and Applied Genetics, Berlin, v.94, p.1023-1030, 1997.

LIU, Z.W.; JARRET, R.L.; DUNCAN, R.R.; KRESOVICH, S. Genetic relationships and variation of ecotypes of seashore paspalum (Paspalum vaginatum) determined by random amplified polymorphic DNA markers. Genome, Ottawa, v.37, p.1011-1017, 1994.

MAAB, H.I.; KLAAS, M. Intraspecific differentiation of garlic (Allium sativum L.) by isozyme and RAPD markers. Theoretical and Applied Genetics, Berlin, v.9, p.189-197, 1995.

N'GORAM, J.A.K.; LAURENT, V.; RISTERUCCI, A.M.; LANAUD, C. Comparative genetic diversity studies of Theobroma cacao L. using RFLP and RAPD markers. Heredity, Oxford, v.73, p.589-597, 1994.

PEER, Y. van de; WACHTER, R. de. Treecon for windows: a software package for the construction and drawing of evolutionary trees for the Microsoft Windows environment. Computer Applications in the Biosciences, Oxford, v.10, p.569-570, 1994.

ROY, A.; FRASCARIA, N.; MacKAY, J.; BOUSQUET, J. Segregating random amplified polymorphic DNAs (RAPDs) in Betula alleghaniensis. Theoretical and Applied Genetics, Berlin, v.85, p.173-180, 1992.

SAITOU, N.; NEI, M. The neighbor-joining method: a new method for reconstructing phylogenetic trees. Molecular Biology and Evolution, Lawrence, v.4, p.406-425, 1987.

SCHMID-HEMPEL, P.; KOELLA, J.C. Variability and its implications for host-parasite interactions. Parasitology Today, Oxford, v.10, p.98-102,1994.

STILES, J.I.; LEMME, C.; SONDUR, S.; MORSHIDI, M.B.; MANSHARDT, R. Using randomly amplified polymorphic DNA for evaluating genetic relationships among papaya cultivars. Theoretical and Applied Genetics, Berlin, v.85, p.976-984, 1993.

SUN, G.L.; DÍAZ, O.; SALOMON, B.; Bothmer, R. von. Microsatellite variation and its comparison with allozyme and RAPD variation in Elymus fibrosus (Schrenk) Tzvel. (Poaceae). Hereditas, Lund, v.129, p.275-282, 1998.

WILliAMS, C.E.; ST. CLAIR, D.A. Phenetic relationships and levels of variability detected by restriction fragment length polymorphism and random amplified polymorphic DNA analysis of cultivated and wild accessions of Lycopersicon esculentum. Genome, Ottawa, v.36, p.619-630, 1993.

WILLIAMS, J.G.K.; KUBELIK, A.R.; LIVAK, K.J.; RAFALSKI, J.A.; TINGEY, S.V. DNA polymorphisms amplified by arbitrary primers are useful as genetic markers. Nucleic Acids Research, Oxford, v.18, p.6531-6535, 1990.

YANG, X.; QUIROS, C. Optimizing the generation of random amplified polymorphic DNAs in chrysanthemum. Theoretical and Applied Genetics, Berlin, v.86, p.1033-1037, 1993. 